\title{
曲げと圧縮が作用する薄肉長方形断面部材の弾性局部座屈耐力および最大耐力 \\ ELASTIC LOCAL BUCKLING STRENGTH AND MAXIMUM STRENGTH OF RECTANGULAR SECTION MEMBERS WHICH WERE LOADED COMPRESSION AND BENDING
}

\author{
小橋 知 季*1, 五十嵐 規矩夫*2, 清 水 信 孝*3 \\ Tomoki KOBASHI, Kikuo IKARASHI and Nobutaka SHIMIZU
}

\begin{abstract}
One of the key issues for the design of cold-formed steel members is the local buckling strength. In this paper, we investigated the local buckling strength of rectangular sections which were loaded a bending moment and an axial compression, simultaneously. Based on the numerical analyses, we found that the local buckling strength of rectangular sections were affected the restraining effect under compression and bending. The design equations for the local buckling strength on rectangular sections were suggested and found that suggested equations could evaluate the elastic local buckling strength and post buckling strength accurately compared with the conventional design method.
\end{abstract}

Keywords : Cold Formed Steel, Elastic Local Buckling Strength, Post Buckling Strength, Rectangular Sections 薄板軽量形鋼，弾性局部座屈耐力，座屈後耐力，長方形断面

\section{1. 序}

中低層の集合住宅等への適用が進みつつあるスチールハウスでは, 板厚 $2.3 \mathrm{~mm}$ 未満のめっき鋼板を冷間成形した薄板軽量形鋼 1)が主 要構造部材として使用される.この薄板軽量形鋼は, 2001 年に国土 交通省より交付された薄板軽量形鋼造に関寸る技術基準(平成 13 年 国交省告示第 1641 号) により建築基準法に基づく建築材料として 指定された材料であり, 幅厚比の大きい板要素で部材断面が構成さ れているのが特徵である. 薄板軽量形鋼に圧縮や曲げの力が作用す ると, 断面内での発生応力が降伏応力に至る前に断面を構成する板 要素に弾性局部座屈が生じ, その後も変形の増加と共に各板要素の 側辺部近傍における発生応力が大きくなることで部材耐力が上昇し て最大耐力（座屈後耐力）に至る, という特徵を示す. 従って薄板 軽量形鋼の設計においては, 部材の弾性局部座屈耐力ならびに最大 耐力を精緻に評価することが重要である.

薄板軽量形鋼の部材耐力を定量的に評価する手法の一つに, 部材 断面を構成する板要素を単純支持板とみなし, 板要素の負担耐力を 有効幅理論 2),3 に基づき計算したうえで, 各板要素の負担耐力を足 し合わせる方法がある。本手法は，日本，米国，欧州など，様々な 国の設計指針 1),4),5) に採用されている.

一方，実際の薄板軽量形鋼では，部材断面を構成する板要素は隣 接する板要素によって板側辺部の回転変形が拘束されるため, 板側 辺部の境界条件は単純支持とは異なる条件となる.そこで筆者らは, この板要素間での拘束効果に着目し, 軸圧縮が作用する長方形断面
部材, 溝形断面部材および八角形断面部材の局部座屈挙動を分析す るとともに，弾性局部座屈耐力および最大耐力に関する耐力評価法 を提案してきた 6,7$), 8$.

ここに，薄板軽量形鋼を用いた実構造物では，部材同士の接合に 金物を介した接合方法が広く用いられており，これらの金物接合部 では, 形鋼の図心と荷重の作用位置との偏心による曲げと圧縮の複 合力が部材に作用する場合も想定される。このような曲げと圧縮の 複合力が作用寸る荷重条件下においても, 前述の板要素間での拘束 効果が発揮されると考えられるが，曲げと圧縮の複合力が作用する 薄板軽量形鋼の座屈後耐力に関する研究例は少なく，また座屈後耐 力に板要素間での拘束効果が及ぼす影響に着目した研究例は, 筆者 らの調べた限りでは見受けられない.

以上を踏まえ，本論文では長方形断面を有する部材に着目し，曲 げと圧縮の複合力が作用する長方形断面部材の弾性局部座屈耐力お よび座屈後耐力に隣り合う板要素間での拘束効果が及ぼす影響を有 限帯板法および有限要素法による数值解析に基づき考察すると共に, 簡易な耐力評価手法の提案に取り組んだ。長方形断面は，閉鎖断面 かつ 2 軸対称の断面形状であり，断面のゆがみが発生しにくく，な おかつねじれ剛性が高い断面形状である。このため，部材全体の不 安定挙動ではなく, 局部座屈によって部材耐力が決定するため, 板 要素間での拘束効果の影響が部材耐力に表れ易い。まず，有限帯板 法による固有值解析により，曲げが作用する長方形断面部材の弾性 局部座屈耐力に部材断面形状が及ぼす影響を分析し，既報 7)にて提

\footnotetext{
*1 新日鐵住金(侏鋼構造研究部 主任研究員 · 修士(工学) 東京工業大学大学院理工学研究科建築学専攻 博士後期課程 (社会人コース)

*2 東京工業大学環境・社会理工学院建築学系 教授・博士(工学)

*3 新日鐵住金(株鋼構造研究部 主幹研究員・博士 (工学)
}

Researcher, Steel Structures Research Lab., Nippon Steel \& Sumitomo Metal Corporation, M.Eng. Grad. Student, Dept. of Architecture and Building Engineering, Tokyo Institute of Technology

Prof., Dept. of Architecture and Building Engineering, Tokyo Institute of Technology, Dr.Eng. Senior Researcher, Steel Structures Research Lab., Nippon Steel \& Sumitomo Metal Corporation, Dr.Eng. 


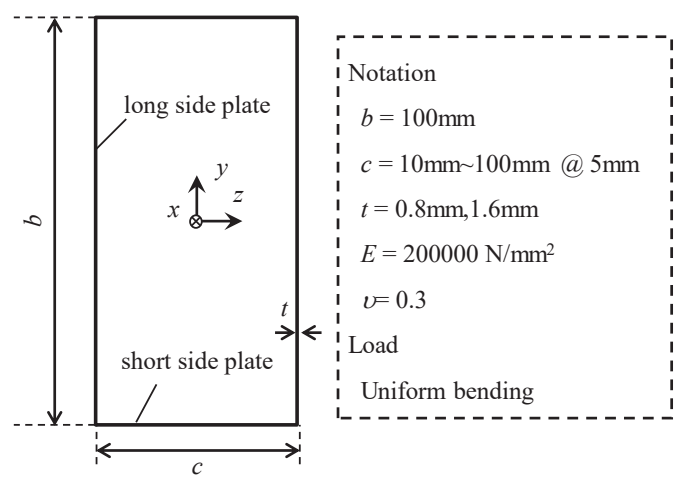

Fig.1 Outline of eigenvalue analysis model

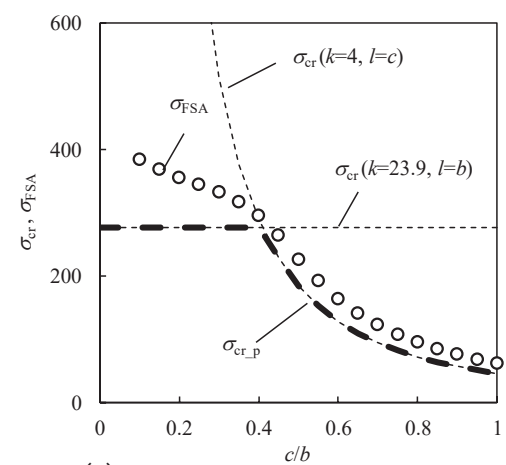

(a) Loaded a moment in $z$ rotation

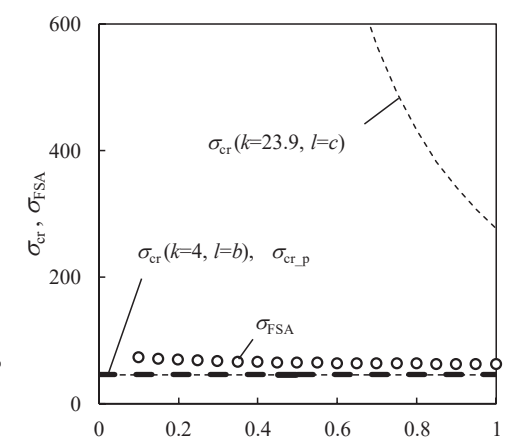

(b) Loaded a moment in $y$ rotation Fig.2 Elastic local buckling strength by Finite Strip Analysis ( $t=0.8 \mathrm{~mm}$ )
案した軸圧縮部材の弾性局部座屈耐力に関寸る評価式について, 曲 げ部材への適用方法を考察する. 次に, 前述の評価式について, 適 用範囲を曲げ圧縮材に拡張寸る手法を考察すると共に, 固有值解析 に基づく解析結果との比較を通じて, その妥当性を検証する. 最後 に, 有限要素法による弾塑性大変形解析を通じて曲げ圧縮が作用す る部材の最大耐力に部材の断面形状が及ぼす影響を分析し, 部材の 最大耐力に関する定量評価を行う。

\section{2. 曲げ圧縮が作用する長方形断面部材の弾性局部座屈耐力}

曲げ圧縮が作用する部材の弾性局部座屈耐力を固有值解析で求め, その耐力評価を行う。まずは, 曲げのみが作用する長方形断面部材 の座屈固有值解析を行い, 隣り合う板要素の板幅の違いが部材の弾 性局部座屈耐力に及ぼす影響を明らかにしたうえで，既報 7)で提案 した軸圧縮部材の弾性局部座屈耐力に対する評価式の適用について 考察する. 次に, 評価手法の適用範囲を曲げ圧縮が作用する場合 拡張する方法を考察すると共に, 固有值解析から得た弾性局部座屈 耐力との比較を通じて，その妥当性を検証する.

\section{1 有限帯板法による座屈固有値解析}

有限帯板法による数值解析ソフト $\mathrm{CU}-\mathrm{FSM}^{2}$ )を用いて等曲げが作 用する長方形断面の弾性局部座屈耐力 $\sigma_{\mathrm{FSA}}$ を計算した. Fig.1 には, 解析モデルの断面形状を示す. 長辺(long side plate)の幅 $b$ を $100 \mathrm{~mm}$ で一定とし, 短辺(short side plate)の幅 $c$ を $10 \mathrm{~mm}$ から $100 \mathrm{~mm}$ まで $5 \mathrm{~mm}$ 間隔で変化させ, 長辺と短辺の辺長比 $c / b$ が部材の弾性局部座 屈耐力に与える影響を調べた。板厚 $t$ は $0.8 \mathrm{~mm}, 1.6 \mathrm{~mm}$ の 2 通りで ある. 荷重は，短辺に一様な軸方向応力が作用し長辺に面内曲げが 作用するように $z$ 軸回りのモーメントを作用させた場合と, 長辺に 一様な軸方向応力が発生して短辺に面内曲げが作用するように $y$ 軸 回りのモーメントを作用させた場合の 2 通りであり, いずれも部材 の図心に曲げモーメントを作用させた。材料は鋼材を想定し, 簡単 のためヤング係数 $E=200000 \mathrm{~N} / \mathrm{mm}^{2}$, ポアソン比 $v=0.3$ とした.

\section{2 等曲げが作用する長方形断面部材の弾性局部座屈耐力}

Fig.2 には解析結果の一例として, $t=0.8 \mathrm{~mm}$ の長方形断面部材の弾 性局部座屈耐力を示す. Fig2(a)が $z$ 軸回りのモーメントを作用させ た場合の解析結果を示し, Fig2(b)が $y$ 軸回りのモーメントを作用さ せた場合の解析結果を示寸. 横軸が $c / b$ (短辺の板要素の板幅 $c$ を長 辺の板要素の板幅 $b$ で除した值)であり, 縦軸が固有值解析から得た 弾性局部座屈耐力 $\sigma_{\mathrm{FSA}}$ である. プロットは解析結果を表し, 2 本の 細破線は長辺および短辺を単純支持板とみなした場合の弾性局部座

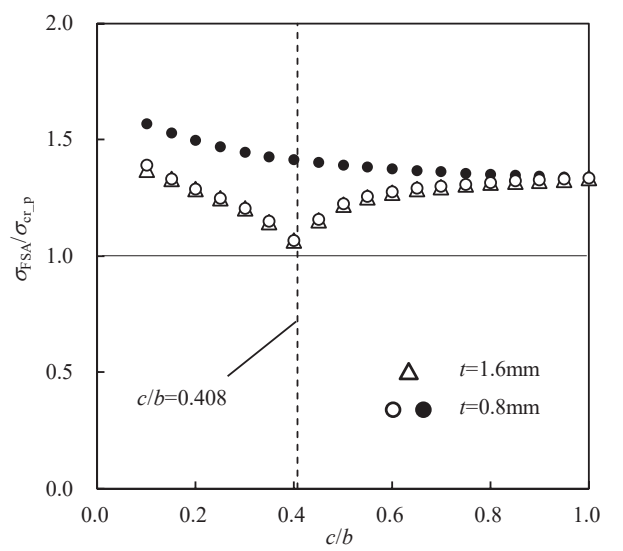

Fig.3 Ratio of actual strength to conventional strength

屈耐力 $\sigma_{\mathrm{cr}}(\mathrm{Eq} .(1))$ を表す. 2 本の細破線が示す計算耐力のうち小さい 方の值(図中の太破線)が，長方形断面を構成する板要素を単純支持 板とみなした場合の弾性局部座屈耐力 $\sigma_{\mathrm{cr} \_\mathrm{p}}$ である.

$$
\sigma_{\mathrm{cr}}=k \frac{E \pi^{2}}{12\left(1-v^{2}\right)}\left(\frac{t}{l}\right)^{2}
$$

ただし $k$ : 板要素の座屈係数

$l:$ 板要素の板幅 $(b$ または $c)$

本解析では, 長辺の幅を一定とした条件のもと, 短辺の幅を変化 させている．このため断面を構成する板要素を単純支持板とみなし た場合, 長辺の弾性局部座屈耐力は一定值となり, 短辺の弾性局部 座屈耐力は $c / b$ の増加と共に減少することとなる. $z$ 軸回りの曲げモ 一メントが作用寸る場合, $c / b$ が小さい領域では長辺の座屈耐力が短 辺の座屈耐力を下回るため $\sigma_{\mathrm{cr} \_\mathrm{p}}$ 計算耐力(図中の太破線)が一定值と なり, $c / b$ が大きくなると, 短辺の弾性局部座屈耐力が長辺の弾性局 部座屈耐力を下回るため, $c / b$ の増加と共に $\sigma_{\mathrm{cr} \mathrm{p}}$ が減少する。 また $y$ 軸回りの曲げモーメントが作用する場合, 長辺の弾性局部座屈耐力 は短辺の弾性局部座屈耐力よりも常に小さくなるため(ただし, $c<b)$, $\sigma_{\text {cr_p }}$ は一定値となる。図より, 固有值解析から得られた弾性局部座 屈耐力 $\sigma_{\mathrm{FSA}}$ は全て $\sigma_{\mathrm{cr} p \mathrm{p}}$ (太破線)を上回り，曲げが作用する部材におい ても, 長方形断面部材の弾性局部座屈耐力は, 断面を構成する板要 素を単純支持板とみなした場合よりも大きくなることが分かる.

続いて， $\sigma_{\mathrm{FSA}} / \sigma_{\text {cr_p }}$ (Fig.2 のプロット $\sigma_{\mathrm{FSA}}$ を太破線 $\sigma_{\text {cr_p }}$ で除した 值) と $c / b$ との関係を Fig. 3 に示寸. 図中の白塗りプロット $(\bigcirc, \triangle)$ が $z$ 軸回りのモーメントを作用させた場合の解析結果を表し, 黒塗り 
プロット )が $y$ 軸回りのモーメントを作用させた場合の解析結果 を表す。図中の破線は, $z$ 軸回りの曲げモーメントが作用する長方 形断面部材において, 面内曲げが作用する長辺と一様な圧縮が作用 する短辺が各々単純支持板として挙動した場合に，双方の弾性局部 座屈耐力が等しくなる断面仕様 $(c / b=0.408)$ を表す. また図中の実線 は, $\sigma_{\mathrm{FSA}} / \sigma_{\text {cr_p }}=1$ を表す.

$z$ 軸回転の曲げモーメントが作用する場合, 破線近傍の $c / b=0.4$ の 断面仕様において $\sigma_{\mathrm{FSA}} / \sigma_{\mathrm{cr} \_\mathrm{P}}$ が最小となることが確認でき, $c / b$ が 0.4 から増減すると $\sigma_{\mathrm{FSA}} / \sigma_{\mathrm{cr} \_\mathrm{p}}$ は増加する傾向を示した. $c / b=0.4$ の断面仕 様では, $\sigma_{\mathrm{FSA}} / \sigma_{\mathrm{cr} \_p}=1.07$ となり, 部材断面を構成する板要素の境界条 件が単純支持に近い状態にあったといえる. $c / b$ が 0.4 よりも大きく なると, 短辺の局部座屈耐力が長辺の局部座屈耐力よりも小さくな ることで，長辺から短辺への拘束が作用し， $\sigma_{\mathrm{FSA}} / \sigma_{\mathrm{cr} \mathrm{p}}$ は増加した。 一方, $c / b$ が 0.4 よりも小さくなると, 長辺の局部座屈耐力が短辺の 局部座屈耐力よりも小さくなることで, 短辺から長辺への拘束が作 用し, $\sigma_{\mathrm{FSA}} / \sigma_{\mathrm{cr} \_\mathrm{p}}$ が増加した.

$y$ 軸回転の曲げモーメントが作用する場合, $\sigma_{\mathrm{FSA}} / \sigma_{\mathrm{cr} \_\mathrm{p}}$ は全て 1.0 よ りも高い值となり,$c / b$ の減少とともに $\sigma_{\mathrm{FSA}} / \sigma_{\mathrm{cr} \_\mathrm{p}}$ は増加する傾向を示 した， $y$ 軸回転の曲げモーメントが作用する場合, 長方形断面部材 の弾性局部座屈は一様な圧縮力が作用する長辺の局部座屈に起因す るものと考えられ，短辺の板幅が小さくなることで，短辺が長辺の 板側辺部を拘束する効果が大きくなり， $\sigma_{\mathrm{FSA}} / \sigma_{\mathrm{cr} \_\mathrm{p}}$ が増加した．

$t=0.8 \mathrm{~mm}$ の解析結果と $t=1.6 \mathrm{~mm}$ の解析結果を比較すると, $\sigma_{\mathrm{FSA}} / \sigma_{\mathrm{cr} \_\mathrm{p}}$ に有意な差は確認できず，板厚の違いが本検討結果に及ぼす影響は 殆どないと分かる。一枚の鋼板を冷間成形して製造する薄板軽量形 鋼では, 断面を構成する板要素の板厚がすべて等しいため, 板要素 の単位幅あたりの面外曲げ剛性も長辺・短辺ともに等しい。既報 ${ }^{7)}$ において, 軸圧縮が作用する長方形断面では板要素間での相互拘束 効果に板厚は影響を及ぼさないことが明らかにされており，等曲げ が作用する場合においても, 同じ傾向が示された.

\section{3. 等曲げが作用する部材の弾性局部座屈耐力の評価}

軸圧縮力が作用する長方形断面部材の弾性局部座屈耐力の評価式 をもとに, 等曲げが作用する長方形断面部材の弾性局部座屈耐力に 対する簡易な評価式の構築に取り組む. 曲げが作用する長方形断面 部材では, 短辺の板要素が局部座屈する場合と, 長辺の板要素が局 部座屈する場合の 2 通りの座屈モードが想定される. そこで本論文 では, 双方の座屈モードに対して, 耐力評価式を提案する.

まず軸圧縮が作用する長方形断面部材の弾性局部座屈耐力に関す る評価式 7)について, 概要を述べる. 小橋らは, 軸圧縮が作用する 長方形断面部材の弾性局部座屈耐力について, 長辺の座屈モード $w(x, y)$ を, 4 辺を単純支持された板要素の変位関数 $w_{\mathrm{p}}(x, y)$ と, 材軸方 向に延びる両側辺部を固定支持された板要素の変位関数 $w_{\mathrm{r}}(x, y)$ との 線形和として近似することで, エネルギー法に基づき座屈係数 $k$ に 対する評価式を以下の通り提案した。ここに, $\gamma$ は板要素間での拘束 度合いを示すパラメータであり， $0 \leqq \gamma \leqq 1$ の範囲で変化する実数で ある。

$$
\begin{aligned}
& w(x, y)=\gamma w_{p}(x, y)+(1-\gamma) w_{r}(x, y) \\
& k=4 \gamma+6.98(1-\gamma)
\end{aligned}
$$

$$
\begin{array}{ll}
0<c / b \leqq 0.1 \text { の場合 } & \gamma=4.6 c / b \\
0.1<c / b \leqq 1.0 \text { の場合 } & \gamma=0.4+0.6 c / b
\end{array}
$$

Eq.(2) Eq.(4-2)は長辺が局部座屈することを想定した評価式であ り, $x$ と $y$ は Fig.1の $x$ 軸, $y$ 軸と一致する.ここに, Eq.(2)を $y$ で偏 微分すると, 板要素に生じる回転角 $\theta$ は Eq.(5)となる.

$$
\begin{aligned}
& \theta(x, y)=\gamma \theta_{p}+(1-\gamma) \theta_{r} \\
& \theta_{p}(x, y)=\frac{\partial w_{p}(x, y)}{\partial y} \\
& \theta_{r}(x, y)=\frac{\partial w_{r}(x, y)}{\partial y}
\end{aligned}
$$

$w_{\mathrm{r}}(x, y)$ は固定端の支持条件を想定した変位関数であることを考慮 すれば, 座屈変形時の板側辺部 $(y= \pm b / 2)$ における回転角は $\theta(x, y)=\gamma \theta_{p}(x, y)$ となる. 従って, $\gamma$ は板側辺部における $\theta(x, \pm b)$ と $\theta_{\mathrm{p}}(x, \pm b)$ の比率であると分かる.

$$
\gamma=\frac{\theta(x, \pm b / 2)}{\theta_{p}(x, \pm b / 2)}
$$

続いて, $z$ 軸回転の曲げモーメントが作用する部材において, 面 内への等曲げが作用する長辺が座屈する場合について考察する，面 内への等曲げが作用する板要素では, 圧縮縁側の側辺部の境界条件 と引張縁側の側辺部の境界条件は異なるものと考えられる。しかし ながら, 両端を単純支持された板要素の座屈係数が 23.9 であるのに 対して,引張縁側の回転変形が拘束された板要素の座屈係数は 24.48 であり ${ }^{9)}$, 両值の比率は 1.02(=24.48/23.9) となることから, 引張縁側 の回転拘束の有無が板要素の座屈係数に及ぼす影響は小さいものと 考えらえる，そこで本論文では，面内曲げが作用寸る板要素の弾性 局部座屈耐力は，圧縮縁側の板側辺部の境界条件による影響を大き くうけるものと考え, 圧縮縁側の側辺部における回転変形に着目し て耐力評価式の構築に取り組んだ.

端部が回転拘束される境界条件を満足するように板要素の面外変 形を数式で表現する場合，例えば無限級数により変位関数を定式化 する手法があるが，煩雑な数式表現になることが多い，そこで本論 文では, 有限要素解析で板要素の弾性局部座屈耐力および座屈モー ドを求め, 座屈係数 $k$ と $\gamma$ 関係, ならびに $\gamma$ と $c / b$ の関係を分析し た.

Fig.4 には解析モデルの概要を示す. 解析は, 汎用の有限要素解析 ソフトMarc を用いた固有值解析である. 部材長さ $300 \mathrm{~mm}$ の長方形 断面を有する角形鋼管部材，および板幅 $100 \mathrm{~mm}$ かつ長さ $300 \mathrm{~mm} の$

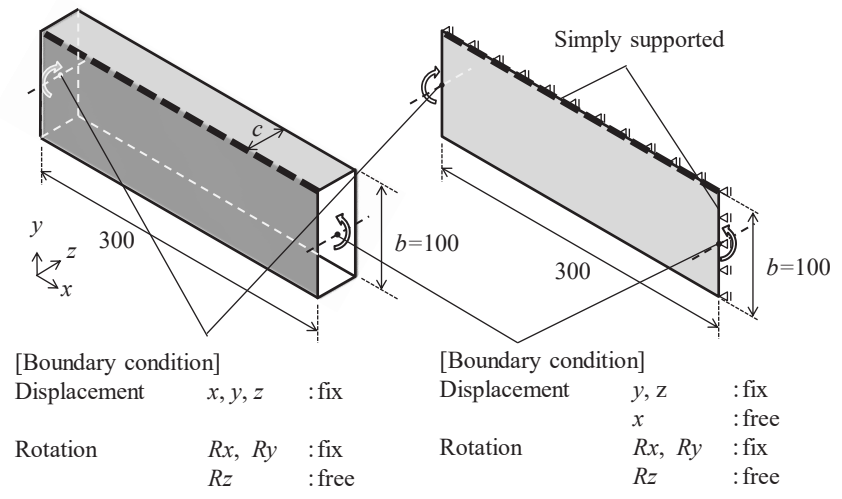

Fig.4 Outline of finite element analysis models 


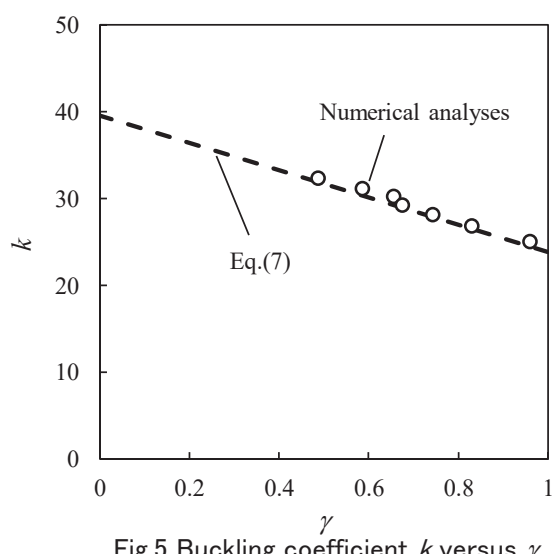

Fig. 5 Buckling coefficient $k$ versus $\gamma$

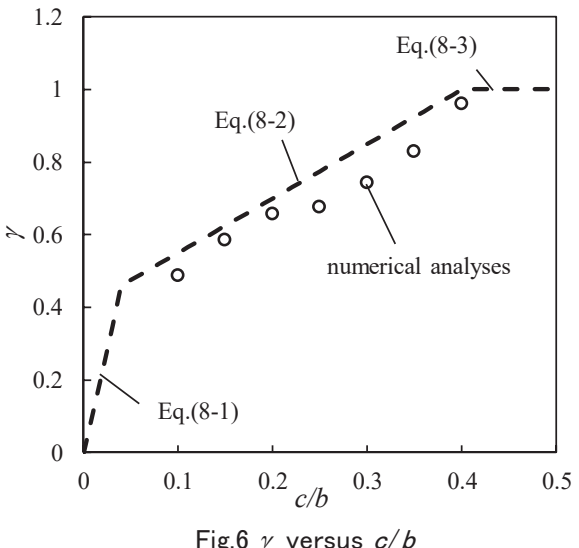

Fig.6 $\gamma$ versus $c / b$

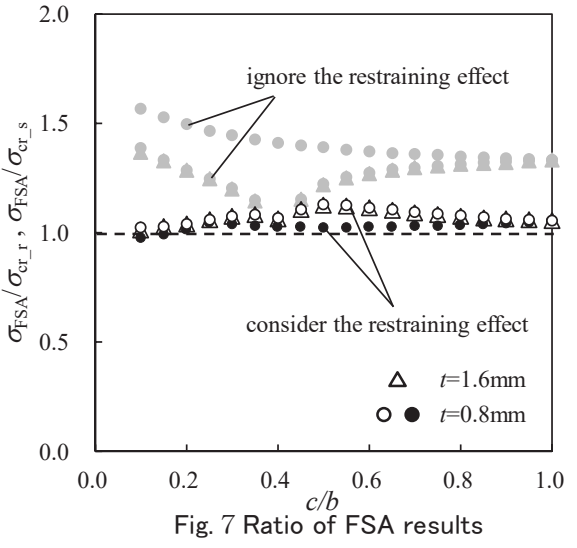

with calculated strength
長方形の板要素の両端部に曲げモーメントを作用させ, 弾性局部座 屈耐力および座屈モードを計算し, 圧縮縁側の板側辺部(図中の太破 線部)に生じる回転角から, Eq.(6)に基づき $\gamma$ を計算した. 解析パラメ 一タは長方形断面の短辺の板幅であり, Fig3 に示した固有值解析結 果を参考に, 長辺の座屈によって部材の弾性局部座屈耐力が決定し たと想定される $c=10 \mathrm{~mm} 40 \mathrm{~mm}$ の範囲を $5 \mathrm{~mm}$ 間隔で変化させた. 板厚は $0.8 \mathrm{~mm}$ である。材料は鋼材を想定し, ヤング係数 $E=$ $200000 \mathrm{~N} / \mathrm{mm}^{2}$,ポアソン比 $v=0.3$ とした.

Fig.5 には, 解析結果から計算した $\gamma$ と, 弾性局部座屈耐力から Eq.(1)をもとに $l=b(=100 \mathrm{~mm})$ の条件で逆算した座屈係数 $k$ との関係 を示す. 図中の破線は, 両端ピン支持の条件 $(\gamma=1, k=23.9)$ と両端固 定端支持の条件 $(\gamma=0, \mathrm{k}=39.6)$ をむすぶ直線(Eq.(7))である.

$$
k=23.9 \gamma+39.6(1-\gamma)
$$

図から, 解析結果は $\gamma$ の減少に伴い $k$ が増加する傾向を示し, な おかつ解析結果と Eq.(7)は良い対応を示した.

Fig.6 には, $\gamma$ と $c / b$ の関係を示寸. 図中のプロットが, 有限要素 解析から得た $\gamma$ と $c / b$ の関係である. 図中の破線は, Eq.(8-1)〜 (8-3) による計算值である. Eq.(8-1)と(8-2)は, $c / b=0.4$ 近傍にて板要素の 境界条件が単純支持に近づくことを考慮し, $c / b=0.4$ の断面仕様にお いて $\gamma=1$ になるように, Eq.(4-1)および(4-2)の $b$ を $0.4 b$ に置き換え た評価式である.また Eq.(8-3)は, $c / b>0.4$ の範囲において, 板同士 の拘束効果は期待できない $(\gamma=1)$ 条件を数式で表現したものである. 計算結果は解析結果をわずかに上回る安全側の評価を示したものの, 両者は良い対応を示した。

$$
\begin{array}{ll}
0<c / b \leqq 0.04 \text { の場合 } \quad \gamma=11.5 \frac{c}{b} \\
0.04<c / b \leqq 0.4 \text { の場合 } \quad \gamma=0.4+1.5 \frac{c}{b} \\
0.4<c / b \text { の場合 } \quad \gamma=1
\end{array}
$$

続いて, 一様な圧縮力が作用寸る圧縮縁側の短辺の板要素の弾性 局部座屈によって部材の弾性局部座屈耐力が決定寸る場合について 考察する. 短辺の板要素では, 板要素内に均一な圧縮応力が作用寸 るため, 板要素の境界条件は両側辺部を等しい回転ばねで回転拘束 された板要素に軸圧縮力が作用する場合に等しい，従って $k$ と $\gamma$ の 関係は Eq.(3)と等しくなり, $c / b$ と $\gamma$ の関係性が分かれば, 拘束効果 を考慮した弾性局部座屈耐力の定量評価が可能である.ここに, $c / b=0.4$ の断面仕様において, 短辺の境界条件は単純支持板に等しく なり, なお且つ $c / b$ の増加にともない $\sigma_{\mathrm{FSA}} / \sigma_{\mathrm{cr} \_\mathrm{p}}$ が大きくなることを 考慮すれば, $c / b>0.4$ (すなわち, $b / c<2.5$ )の範囲では, $c / b$ の減少(すな わち， $b / c$ の増加)に伴い拘束効果が大きくなると分かる．この傾向 は，有限要素法に基づく固有值解析からも確認している(付録 A). 従って, 本論文では $b / c$ と $\gamma$ は Fig.6 と類似の傾向を示すと考え, Eq.(4-1),(4-2)の $c / b$ を 0.4b/c に置き換えることで下式を得た。 ここ に， $b / c>2.5$ の場合には，板要素間での拘束効果の発揮が期待できな いと考え, Eq.(9-3)の条件 $(\gamma=1)$ を追加している.

$$
\begin{array}{ll}
0<b / c \leqq 0.25 \text { の場合 } & \gamma=1.84 \frac{b}{c} \\
0.25<b / c \leqq 2.5 \text { の場合 } & \gamma=0.4+0.24 \frac{b}{c} \\
2.5<b / c \text { の場合 } & \gamma=1
\end{array}
$$

最後に, $y$ 軸回りの曲げモーメントが作用する場合について考察 する. $y$ 軸回りの曲げモーメントが作用する場合, $c<b$ より圧縮縁側 の板要素の板幅は面内曲げが作用する板要素の板幅よりも必ず大き い. 従って $y$ 軸回転の曲げモーメントが作用する長方形断面部材で は, 必ず圧縮縁側の長辺が先行して局部座屈を生じるものと考えら れ, 板要素の境界条件は $z$ 軸回りの曲げモーメントが作用した際の 短辺と等しい. 従って, $k$ と $\gamma$ の関係は Eq.(3)と等しくなり, また $\gamma$ と $c / b$ の関係は Eq.(9-1)〜(9-3)の $c$ と $b$ を入れ替えた Eq.(10-1)〜(10-3) となる.なお, 解析結果と提案式の比較は付録 $\mathrm{A}$ に示寸通りである.

$$
\begin{array}{ll}
0<c / b \leqq 0.25 \text { の場合 } & \gamma=1.84 \frac{c}{b} \\
0.25<c / b \leqq 2.5 \text { の場合 } & \gamma=0.4+0.24 \frac{c}{b} \\
2.5<c / b \text { の場合 } & \gamma=1
\end{array}
$$

Eq. (7)と Eq.(8-1) (8-3), Eq.(3)と Eq.(9-1) (9-3), および Eq.(3) と Eq.(10-1) (10-3)を用いて等曲げが作用する長方形断面部材の弾 性局部座屈耐力 $\sigma_{\mathrm{cr} \_ \text {r }}$ を計算し， $\sigma_{\mathrm{FSA}} / \sigma_{\mathrm{cr} \_\mathrm{r}}$ と $c / b$ の関係を調べた。結 果を Fig.7 に示す. 図より, 本論文での提案式は, 部材断面を構成 する板要素を単純支持板とみなした場合よりも精度の良い評価結果 を与えたと分かる．等曲げを受ける長方形断面部材では，面内曲げ が作用する板要素の板幅を見かけ上 0.4 倍の板幅を有する板要素之 みなすことで, 軸圧縮が作用する長方形断面部材と類似の数式を用 いて部材の弾性局部座屈耐力を簡易に評価することができる. 


\section{4 曲げ圧縮が作用する部材の弾性局部座屈耐力の評価}

曲げと圧縮の複合力が作用する長方形断面部材の弾性局部座屈耐 力に断面形状が及ぼす影響を固有值解析に基づき分析し, 軸圧縮, 曲げ，曲げ圧縮が作用する長方形断面の弹性局部座屈耐力を評価で きる簡易な耐力評価式を提案する. 曲げ圧縮が作用する部材では, 等曲げが作用する部材と同様に, 面内曲げと圧縮の複合力が作用寸 る板要素が局部座屈する場合と, 一様な圧縮力が作用する板要素が 局部座屈する場合の 2 通りの座屈モードが想定される. 従って本論 文では，双方の座屈モードに対して簡易な評価式を提案する.

まず，面内曲げと圧縮の複合力が作用する板要素の局部座屈によ って部材の弾性局部座屈耐力が決定する部材の $\gamma$ と $k$ 関係ならび に $c / b$ と $\gamma$ 関係について考察する. 前節に示した通り, 等曲げが作 用寸る長方形断面部材では, 面内曲げが作用寸る板の座屈係数は, 板要素の境界条件を単純支持とみなした場合の座屈係数と, 板側辺 部の境界条件を固定支持とみなした場合の座屈係数の線形和として 近似できた。また同様な仮定は，軸圧縮が作用する長方形断面部材 についても成立する ${ }^{7)}$. 従って, 曲げと圧縮の複合力が作用する場 合において板要素の座屈係数 $k$ は, 境界条件を単純支持とみなした 板要素の座屈係数 $k_{\mathrm{p}}$ と, 固定支持とみなした場合の座屈係数 $k_{\mathrm{r}}$ の線 形和として下式のように近似できると仮定した.

$$
k=\gamma k_{p}+(1-\gamma) k_{r}
$$

ただし $k_{\mathrm{p}}$ ：境界条件を単純支持とみなした場合の座屈係数 $k_{\mathrm{r}}$ ：境界条件を固定支持とみなした場合の座屈係数

単純支持された板要素に曲げ圧縮が作用する場合の座屈係数 $k_{\mathrm{p}}$ についてはすでに数多くの研究がなされており, 例えば文献 4)に 記載の通り, Eq.(12)に示寸経験式が知られている. 与式は, 断面 内に一様な圧縮力が作用する場合 $\left(f_{2} / f_{1}=1\right)$ には $k=4$ となり軸圧縮が 作用する単純支持板の座屈係数を等しくなり, また等曲げが作用す る場合 $\left(f_{2} / f_{1}=-1\right)$ には $k=24$ となり等曲げが作用する単純支持板の座 屈係数 $(k=23.9)$ と一致する.

$$
k_{p}=4+2\left\{\left(1-\frac{f_{2}}{f_{1}}\right)^{3}+\left(1-\frac{f_{2}}{f_{1}}\right)\right\}
$$

ただし $f_{1}$ : 引張縁側の発生応力

$f_{2}$ :圧縮縁側の発生応力

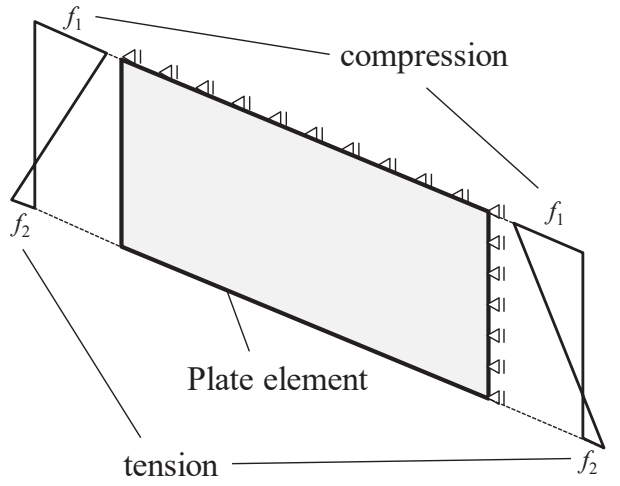

Fig.8 Definition of $f_{1}$ and $f_{2}$

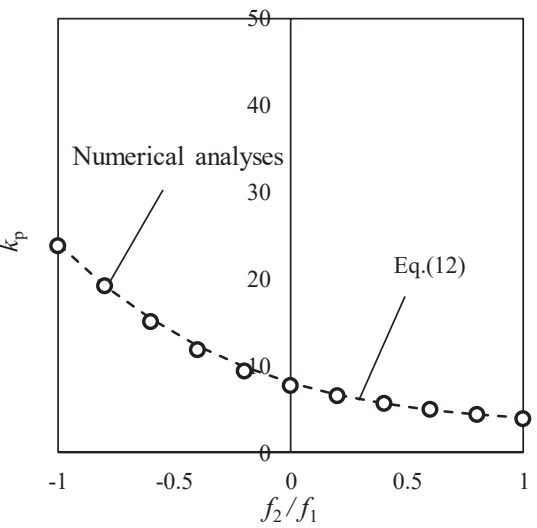

(a) Simply supported

$$
k_{r}=6.98+3.26\left\{\left(1-\frac{f_{2}}{f_{1}}\right)^{3}+\left(1-\frac{f_{2}}{f_{1}}\right)\right\}
$$

Fig.9 には, 座屈係数と $f_{2} / f_{1}$ との関係を示す.プロットは有限帯板 法による固有值解析から求めた座屈係数と $f_{2} / f_{1}$ との関係を表し, 破 線は Eq.(12)および Eq.(13)から求めた計算結果を表す. Eq.(12) およ び Eq.(13)による計算結果は, いずれも解析結果とよい対応を示した。 続いて $c / b$ と $\gamma$ の関係について述べる. 等曲げが作用する長方形断 面部材では, 面内曲げが作用する板要素を, 板幅が 0.4 倍の板要素 とみなすことで, $c / b$ と $\gamma$ の関係を軸圧縮が作用する長方形断面部材 と同じ数式で定量的に評価できた。この特徵に着目し, 面内曲げと 圧縮の複合力が作用寸る板要素の板幅を $\alpha$ 倍寸ることで，評価式の 構築を試みた．以下に，提案式を示す．Eq.(14-1)，(14-2)は，Eq.(31)，(3-2)をもとに，面内曲げが作用する板要素の板幅を $\alpha$ 倍した式 である. Eq.(14-3)は，隣接する板要素からの回転拘束が期待できな い断面仕様を表す数式である. $\alpha$ は, 等曲げ時 $\left(f_{2} / f_{1}=-1\right)$ には $\alpha=0.4$ と なり, 軸圧縮時 $\left(f_{2} / f_{1}=1\right)$ には $\alpha=1$ となる数式(Eq.(15))で計算すること とし，軸圧縮，曲げ圧縮，等曲げのいずれの条件も評価できる形と した.

$$
\begin{array}{ll}
0<l_{c} / l_{b} \leqq 0.1 \alpha \text { の場合 } & \gamma=4.6 \frac{l_{c}}{\alpha l_{b}} \\
0.1 \alpha<l_{c} / l_{b} \leqq \alpha \text { の場合 } & \gamma=0.4+0.6 \frac{l_{c}}{\alpha l_{b}} \\
\alpha<l_{c} / l_{b} \text { の場合 } & \gamma=1 \\
\alpha=0.7+0.3 \frac{f_{2}}{f_{1}} &
\end{array}
$$

ただし $\quad l_{\mathrm{b}}$ :面内曲げが作用する板要素の板幅

$l_{\mathrm{c}}$ : 面内曲げが作用する板要素に隣接する板要素の板幅 
最後に, 圧縮縁側の一様圧縮が作用する板要素が先行して座屈す る場合について述べる. 圧縮縁側の板要素の局部座屈を考える場合, $k$ と $\gamma$ の関係は Eq.(3)で表すことができるため, $c / b$ と $\gamma$ の関係を定式 化できれば，座屈係数を陽な数式で評価することができる．また等 曲げを受ける長方形断面部材の場合, $z$ 軸回転のモーメントが作用 する部材ならびに $y$ 軸回転のモーメントが作用する部材の弾性局部 座屈耐力は, 面内曲げが作用する板要素を板幅が 0.4 倍の板要素と みな寸ことで, 軸圧縮が作用する長方形断面部材の弾性局部座屈耐 力式を用いて定量評価できた. 以上の結果を踏まえ, 面内曲げと圧 縮の複合力が作用する板要素を板幅が $\alpha$ 倍の板要素とみなすことで, 下式を得た。

$$
\begin{array}{ll}
0<l_{b} / l_{c} \leqq 0.1 / \alpha \text { の場合 } & \gamma=4.6 \alpha \frac{l_{b}}{l_{c}} \\
0.1 / \alpha<l_{\mathrm{b}} / l_{\mathrm{c}} \leqq 1 / \alpha \text { の場合 } & \gamma=0.4+0.6 \alpha \frac{l_{b}}{l_{c}} \\
1 / \alpha<l_{\mathrm{b}} / l_{\mathrm{c}} \text { の場合 } & \gamma=1
\end{array}
$$

提案式の妥当性を検証すべく, 軸圧縮力と $z$ 軸回転のモーメント が同時に作用する場合, および軸圧縮力と $y$ 軸回転のモーメントが 同時に作用する場合について, 有限帯板法による固有值解析を実施 し, 提案式に基づく計算結果との比較を行った. Table1 には解析パ ラメータの一覽を示寸. $c / b$ を 0.1 から 1 まで 0.1 間隔で変化させる とともに, $f_{2} / f_{1}$ を- 1 から 1 まで 0.2 間隔で変化させることで, 断面仕 様の違いが曲げ圧縮部材の弾性局部座屈耐力に及ぼす影響を定量評 価した。 なお, 部材の断面仕様は Fig.1 に示寸長方形断面部材と同 じである，板厚は，軸圧縮および等曲げの両検討において，板厚の 違いが座屈係数には影響を及ぼさなかったことを考慮し, $t=0.8 \mathrm{~mm}$ で一定とした. 材料特性やその他解析における諸条件は, 2.1. 節で述

\begin{tabular}{|c|c|c|c|c|c|}
\hline & $\begin{array}{c}b \\
(\mathrm{~mm}) \\
\end{array}$ & $\begin{array}{c}c \\
(\mathrm{~mm}) \\
\end{array}$ & $\begin{array}{c}t \\
(\mathrm{~mm}) \\
\end{array}$ & $f_{2} / f_{1}$ & number of analyses \\
\hline $\begin{array}{c}\text { Analyses which were loaded } \\
z \text { rotation moment }\end{array}$ & 100 & $\begin{array}{c}10 \sim 100 \\
@ \text { a } 10\end{array}$ & 0.8 & $\begin{array}{l}-1 \sim 1 \\
\text { @ } 0.2\end{array}$ & 110 \\
\hline $\begin{array}{c}\text { Analyses which were loaded } \\
y \text { rotation moment }\end{array}$ & 100 & $\begin{array}{c}10 \sim 90 \\
\text { (a) } 10\end{array}$ & 0.8 & $\begin{array}{l}-1 \sim 1 \\
\text { (a) } 0.2\end{array}$ & 99 \\
\hline \multicolumn{6}{|c|}{ total } \\
\hline
\end{tabular}
べた有限帯板法による固有值解析と同じである.

Table 1 Analysis parameters

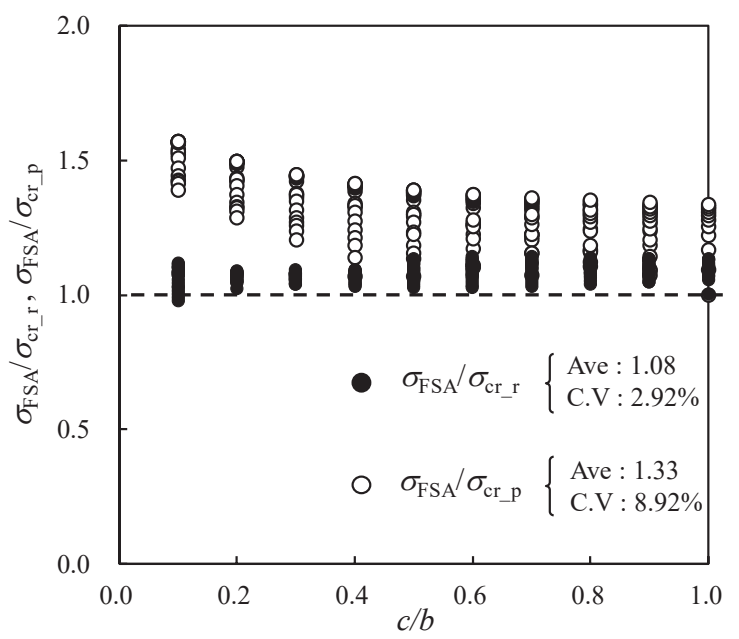

Fig.10 Ratio of analysis results with calculated results
Fig.10には解析結果と計算耐力の比率を示す. 図の縦軸は $\sigma_{\mathrm{FSA}} / \sigma_{\mathrm{cr} \_\mathrm{r}}$ (拘束効果を考慮した弾性局部座屈耐力の計算值 $\sigma_{\mathrm{cr} \_\mathrm{r}}$ で $\sigma_{\mathrm{FSA}}$ を除した 值)および $\sigma_{\mathrm{FSA}} / \sigma_{\mathrm{cr} \_\mathrm{p}}$ (拘束効果を無視した単純支持板の弾性局部座屈 耐力 $\sigma_{\mathrm{cr} \_}$で $\sigma_{\mathrm{FSA}}$ を除した值)を表し, 横軸が $c / b$ を表す. 黒色プロッ トが端部拘束の影響を考慮した場合の結果を示し, 白色プロットが 拘束効果を無視した場合の結果である.Ave および C.V.はそれぞれ プロットの平均值と変動係数を表す．板要素間での相互拘束を考慮 しない場合, 解析結果と計算耐力の比率は 1.00 1.57 の間に分布し, なお且つ $c / b$ が小さくなるにつれて $\sigma_{\mathrm{FSA} A} / \sigma_{\mathrm{cr} \_\mathrm{p}}$ は大きくなる傾向を示 した。一方, 隣接する板要素間での拘束効果を考慮した場合, $\sigma_{\mathrm{FSA}} / \sigma_{\mathrm{cr} \_}$は 0.98 1.14 に分布しており, $c / b$ の值によらず概ね一定の 值となった. 計算耐力と解析結果との比率の平均值および変動係数

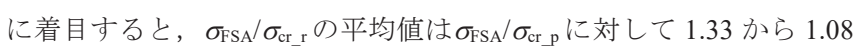
に減少し, 変動係数も $8.92 \%$ から $2.92 \%$ に減少した。提案式によっ て板要素間での拘束効果を考慮することで, 軸圧縮, 等曲げおよび 軸圧縮と曲げの組み合わせ力が作用する長方形断面部材の弾性局部 座屈耐力を従来の単純支持板とみなした場合よりも精度よく評価で きると言える。

\section{3. 曲げ圧縮が作用する長方形断面部材の最大耐力}

有限要素法による弾塑性大変形解析を通じて, 曲げ圧縮が作用す る長方形断面部材の最大耐力に部材の断面形状が及ぼす影響を分析 し，2 章で示した提案式を活用した最大耐力の定量評価に取り組む. まず有効幅理論に基づく部材耐力の評価について, 圧縮力と $z$ 軸 回りの曲げモーメントが作用する部材の長辺の板要素を例に, 概要 を述べる. 板要素の負担耐力を評価する場合, 各板要素の有効幅 $b_{\mathrm{e}}$ は低減係数 $\rho$ を用いて下式で評価される.

$$
b_{e}=\rho b
$$

ここに, $\rho$ は一般化幅厚比 $\lambda\left(=\sqrt{\sigma_{y} / \sigma_{c r}}\right)$ を用いて算出される值であ り, 設計指針によって異なる設計式が採用されている. 代表例として,

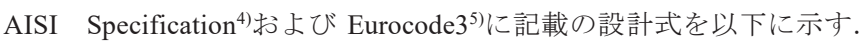
- AISI Specification

$$
\begin{array}{ll}
\lambda>0.673 \text { の場合 } & \rho=\frac{1-0.22 / \lambda}{\lambda} \\
\lambda \leq 0.673 \text { の場合 } & \rho=1
\end{array}
$$

- Eurocode3

$$
\begin{aligned}
& \lambda>0.5+\sqrt{0.085-0.055 \psi} \text { の場合 } \rho=\frac{1-0.055(3+\psi) / \lambda}{\lambda} \\
& \lambda \leq 0.5+\sqrt{0.085-0.055 \psi} \text { の場合 } \rho=1 \\
& \text { ただし } \quad \lambda=\sqrt{\sigma_{y} / \sigma_{c r}} \\
& \psi=f_{2} / f_{1}
\end{aligned}
$$

両設計指針とも, winter の提唱する有効幅の評価式 ${ }^{3)}$ を元に面内 曲げが作用する板要素の有効幅を評価するものであり， $\psi=1$ の場合 に Eq.(19-1)，(19-2)は Eq.(18-1)，(18-2)と同じ式になる. 以上から求 
Table 2 Design equations of effective width

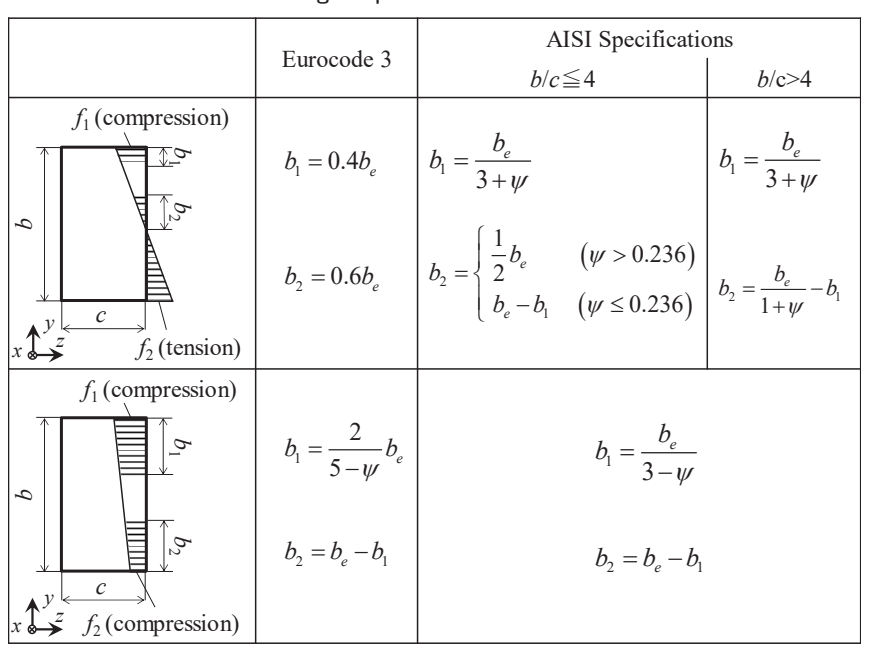

まる $b_{\mathrm{e}}$ を基に, Table2 に示す通り $b_{1}$ および $b_{2}$ を計算することで材 軸方向に発生する応力分布 $\sigma_{x}(y)$ を仮定し, 負担軸力および曲げモー メントを下式で算出する，なお， $b_{1}, b_{2}$ の評価式は設計指針によっ て異なる式が採用されている. AISI Specification出ならびに Eurocode $3^{5)}$ の設計式を，併せて Table 2 に示す.

板要素の負担軸力

$$
N_{\mathrm{PL}}=t \int_{-l / 2}^{l / 2} \sigma_{x}(y) d y
$$

板要素の負担曲げモーメント

$$
M_{\mathrm{PL}}=t \int_{-l / 2}^{l / 2} y \sigma_{x}(y) d y
$$

$$
\begin{aligned}
& \text { ただし } \sigma_{x}(y) \text { : 板要素内の材軸方向の応力分布を表す関数 } \\
& l \quad: \text { 板要素の板幅(長辺の場合 } l=b) \\
& N_{\mathrm{PL}}: \text { 板要素の負担軸力の計算値 } \\
& M_{\mathrm{PL}} \quad \text { : 板要素の負担曲げモーメントの計算值 }
\end{aligned}
$$

ここに, AISI の設計式 ${ }^{4)}$ では, $h_{0} / b_{0} \leqq 4$ かつ $\psi=0.236$ の場合に, $b_{2}$ の值が不連続な值となることが式から確認でき, 曲げ圧縮が作用す る部材の最大耐力を連続的に評価する事には不向きであると考える. 従って本論文では, Eurocode $3^{5)}$ の設計式を基に部材の耐力評価を行 い，端部拘束効果が部材の最大耐力に及ぼす影響を考察した.

\section{1. 有限要素解析の解析モデル概要}

Fig.11 には解析モデルの概要を示す. Fig.11(a)が $y$ 方向に偏心した 圧縮力が作用寸る解析モデルの概要であり, Fig.11(b)が $z$ 方向に偏 心した圧縮が作用寸る解析モデルの概要である. 解析モデルは, 4 節 点シェル要素を用いた有限要素解析モデルである。ソルバーには汎 用の FEM 解析ソフト(Marc2014r1)を使用した，解析モデルは，部材 長さ $300 \mathrm{~mm}$ ，長辺の板幅 $100 \mathrm{~mm}$ の閉断面形状を有する．板厚は $t=0.8 \mathrm{~mm}, 1.6 \mathrm{~mm}$ の 2 通りである. 各モデルとも, 長辺の板要素を 板幅方向へ 40 分割し, 短辺の板要素を板幅に合わせて $10 \sim 40$ 分割 した．また，材軸方向には長辺の板要素，短辺の板要素ともに 150 分割し,シェル要素が極端な長方形形状とならないように配慮した. 部材の両端は図心位置と端部の節点を剛体要素で剛接し,材端での 局所変形を防止した。形状初期不整は，既往の文献 6),7)を参考に，座 屈固有值解析で求めた変形モードに基づき, 最大変形量が板厚の $10 \%$ になるように与えた。なお，冷間加工に伴う残留応力について は，残留応力によって角部が早期に降伏する影響と冷間成形によっ て角部の降伏強度が上昇する効果が相殺されるものと仮定し, 本モ デルでは無視した，素材の応力度-ひずみ度関係(Fig.12)には, 既報 ${ }^{6}$ にて JIS 規格の Z2241に基づき行った材料引張試験の結果をもとに, ひずみが $1 \%$ 以下の領域の応力度-ひずみ度曲線をマルチリニアでモ デル化した。降伏条件にはvon Mises の降伏条件を使用し, 関連流 れ則および等方硬化則に基づき材料特性をモデル化している。なお 文献 7)と同様に，ひずみが $1 \%$ よりも大さ領域では素材強度 6を 一定とし，ひずみ硬化による影響は無視した．Table 4 には解析パラ メータの一覧を示す，本解析では，部材の長さと長辺の板幅を一定 のもと, 短辺の板幅 $c$, 板厚 $t$, 図心から載荷点までの偏心距離 $e$ を パラメータとした解析を実施した。載荷は, 部材の図心から $z$ 方向 または $y$ 方向へ $0 \mathrm{~mm} \sim 640 \mathrm{~m}$ 偏心した位置に軸圧縮力を作用させる ことで曲げと圧縮の複合力を作用させた(付録 B).

\section{2. 最大耐力と計算耐力の比較}

Fig.13には, 有限要素解析から得た部材の最大耐力と, 断面を構 成する板要素が単純支持板として挙動すると仮定した計算耐力との 比較を示す．プロットが解析で得られた最大耐力を表し，実線が Eurocode 3 に基づく計算耐力を表し，破線が全断面有効と仮定した 場合の降伏耐力を表す，縦軸，横軸は，全断面有効で計算した軸圧 縮時および等曲げ時の降伏耐力 $N_{\mathrm{y}}, M_{\mathrm{y}}$ で無次元化した值である.

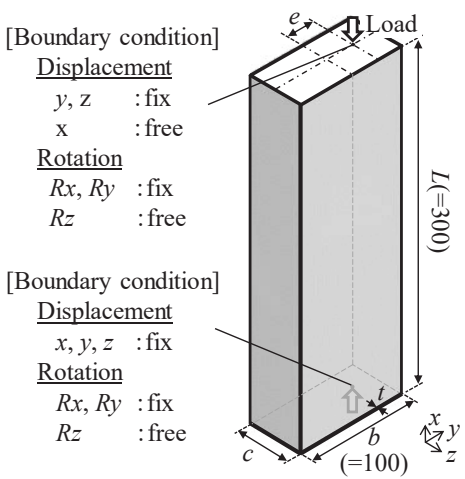

(a) Analysis model in which compression eccentric in $y$ direction was loaded

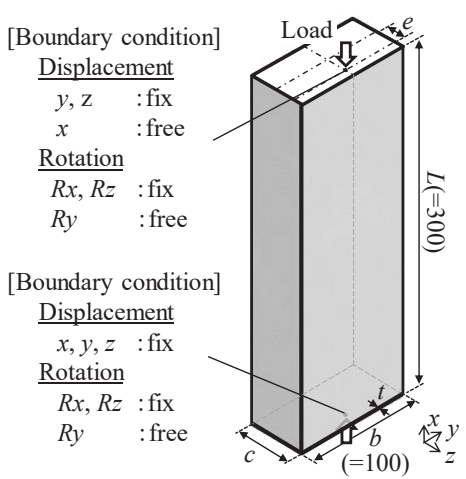

(b) Analysis model in which compression

\begin{tabular}{|c|c|c|c|}
\hline & & $t=0.8 \mathrm{~mm}$ & $t=1.6 \mathrm{~mm}$ \\
\hline & $b(\mathrm{~mm})$ & 100 & 100 \\
\hline & $c(\mathrm{~mm})$ & 10 100@10 & 10 100@10 \\
\hline \multirow{2}{*}{$\begin{array}{c}e \\
(\mathrm{~mm})\end{array}$} & $y$ direction & $\begin{array}{l}0,20,40,80 \\
160,320,640\end{array}$ & $\begin{array}{l}0,20,40,80 \\
160,320,640\end{array}$ \\
\hline & $z$ direction & $0,20,40,80,160$ & \\
\hline
\end{tabular}
eccentric in $z$ direction was loaded

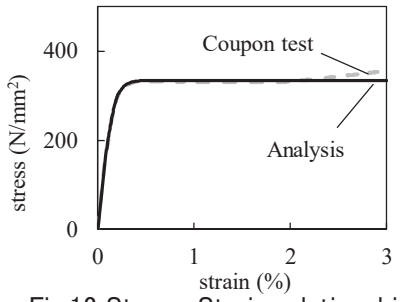

Fig.12 Stress-Strain relationship

Table 3 Material properties
\begin{tabular}{|c|c|}
\hline Thickness $(\mathrm{mm})$ & 0.813 \\
\hline $\begin{array}{r}\text { Yield stress }\left(\mathrm{N} / \mathrm{mm}^{2}\right) \\
(0.1 \% \text { offset })\end{array}$ & 315 \\
\hline Tensile Strength $\left(\mathrm{N} / \mathrm{mm}^{2}\right)$ & 439 \\
\hline Yield ratio $(\%)$ & 75.1 \\
\hline Elongation $(\%)$ & 33 \\
\hline
\end{tabular}

Table 4 Analysis parameters 

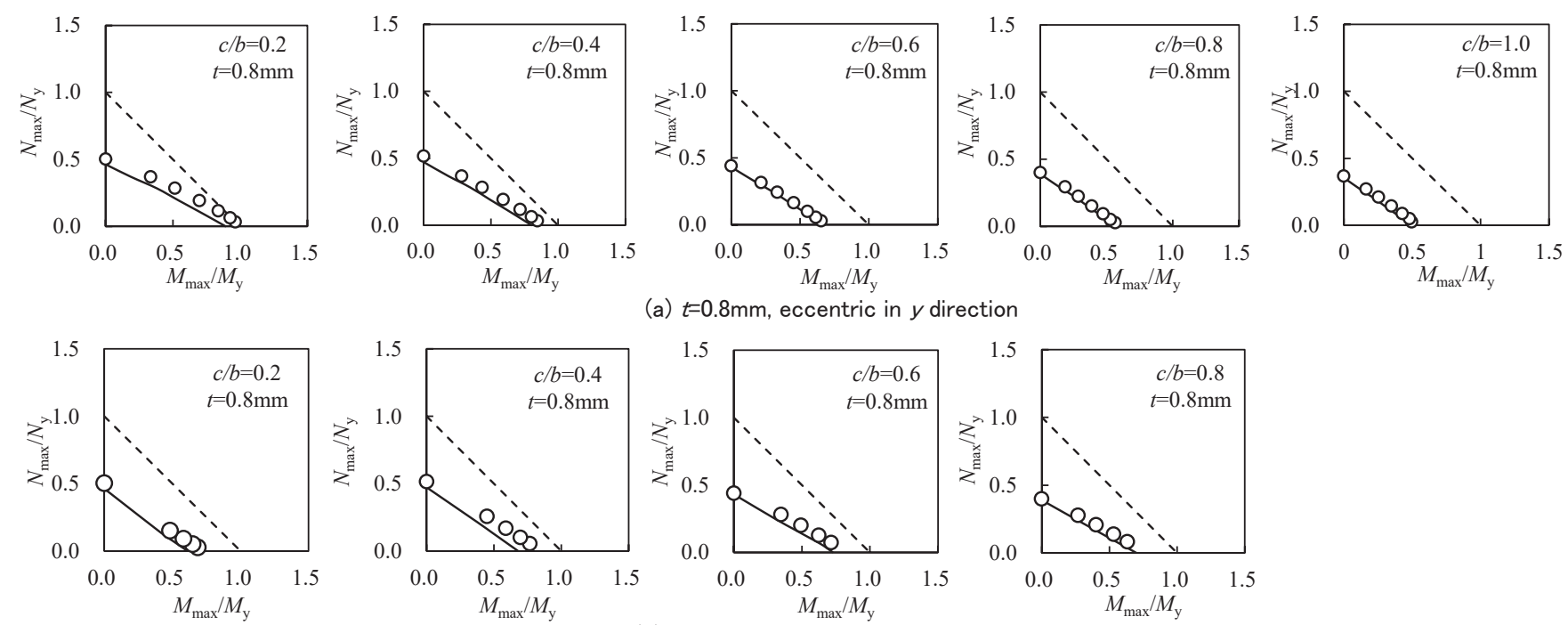

(a) $t=0.8 \mathrm{~mm}$, eccentric in $y$ direction
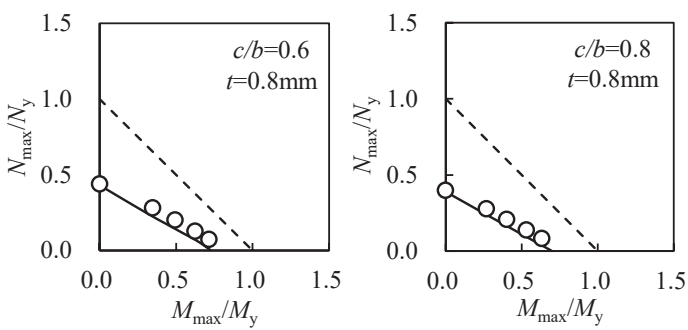

(b) $t=0.8 \mathrm{~mm}$, eccentric in $z$ direction
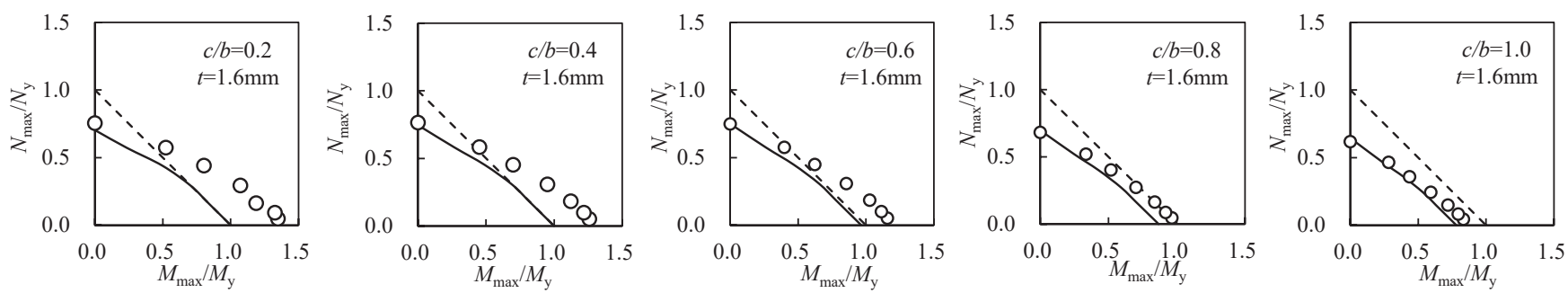

(c) $t=1.6 \mathrm{~mm}$, eccentric in $y$ direction

Fig.13 Maximum strength of rectangular sections under compression and bending

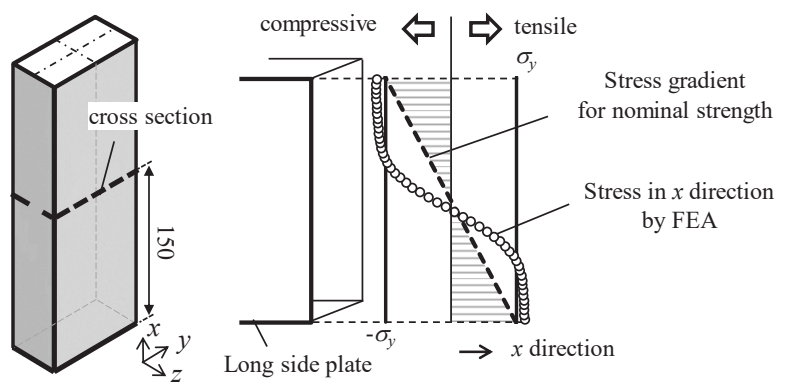

Fig.14 Stress gradient on the long side plate elements in $x$ direction ( $b=100 \mathrm{~mm}, c=40 \mathrm{~mm}, t=1.6 \mathrm{~mm}$, and $e=640 \mathrm{~mm}$ )

$t=0.8 \mathrm{~mm}$ の長方形断面部材に軸圧縮と曲げの複合力が作用する場 合, $z$ 軸回りのモーメントが作用する場合と $y$ 軸回りのモーメント が作用する場合のいずれにおいても, プロットは概㸚直線形状に分 布し, $N_{\max } / N_{\mathrm{y}}$ の減少とともに $M_{\max } / M_{\mathrm{y}}$ が増加した. 計算耐力と最大 耐力を比較すると，軸圧縮のみが作用する場合において最大耐力が 計算耐力をわずかに下回る場合も見受けられたものの, 部材の最大 耐力は計算耐力と概ね同等以上の值となり, 例えば $c / b=0.4$ の断面 仕様では, 計算耐力が解析で得られた最大耐力を $20 \%$ 以上安全側に 評価するなど，最大耐力を計算耐力が過小評価する断面仕様も多く 見受けられた，板要素を単純支持板とみな寸既往の設計法は, 長方 形断面部材の最大耐力の下限值を評価できる一方で, 部材耐力を精 緻に評価する評価手法ではないと分かる.

$t=1.6 \mathrm{~mm}$ の長方形断面部材に軸圧縮と強軸曲げの複合力が作用す る場合, $t=0.8 \mathrm{~mm}$ の場合と同様に, 軸圧縮解析において, 最大耐力 が計算耐力をわずかに下回ったものの, 総じて計算耐力は解析結果
を過小評価する傾向が確認でき，また $c=20 \mathrm{~mm}, 40 \mathrm{~mm}$ および $60 \mathrm{~mm}$ の解析では, 最大耐力が降伏耐力を上回る場合も確認された.

ここに, 最大耐力が降伏耐力を上回った代表例として, $b=100 \mathrm{~mm}$, $c=40 \mathrm{~mm}, t=1.6 \mathrm{~mm}$ の部材に $e=640 \mathrm{~mm}$ の偏心を与えた解析について, 最大耐力時に $x=150 \mathrm{~mm}$ の部材断面位置で長辺に生じた $x$ 方向の応 力分布を Fig.14 に示す.プロットが解析結果を示し，破線が計算耐 力を算出する際に仮定した応力分布を示寸。薄板軽量形鋼を用いた 建築構造物において，パネルの枠材や屋根卜ラスは，建物が終局状 態に至るまで損傷を生じない部材として使用寸る，このため，構造 設計においても材料降伏後の耐力上昇を見込んだ設計は実施されて おらず，図中に破線で示寸通りの直線的な応力分布を仮定して部材 耐力を評価する。一方, 実際の構造物では, 板厚が厚くなることで 局部座屈耐力が上昇し, 最大耐力時の長辺の応力分布は降伏耐力を 超えて S 字形の非線形状となる(図中の白プロット). 部材の圧縮縁 および引張縁が材料降伏に達した後も, 塑性変形にともない長辺の 負担耐力上昇したことで, 最大耐力と計算耐力との間に差が生じた.

\section{3. 端部拘束効果を考慮した最大耐力の評価}

隣り合う板要素の板幅の違いによって生じる相互拘束効果を考慮 した曲げ圧縮部材の最大耐力に関する耐力評価法について考察する. 前述の通り，パネル部材の枠材や屋根トラスに薄板軽量形鋼を用い た建物では, 構造物が終局状態に至るまで形鋼には損傷を生じさせ ないという設計思想に基づき部材設計を行う。従って, 材料降伏後 の耐力上昇を設計上見込むことは，想定外の外乱が建物に作用した 場合に設計者の予期せ女損傷を生じる危険性があるため，積極的に は用いられない。一方，最大耐力が降伏耐力を下回る場合について 
は, 設計耐力と実耐力との乘離を少なくさせることで, より経済的 な設計が実現できる可能性があり, 耐力評価法の高精度化が重要で ある. そこで本論文では, 有限要素解析結果で得られた部材耐力が 降伏耐力を下回った部材について, 計算耐力と部材耐力との比率に 隣り合う板要素間での拘束が及ぼす影響について考察した。

軸圧縮が作用する部材の最大耐力に着目した場合, 板要素間での 拘束効果は弾性局部座屈耐力が低い長辺の座屈後耐力に対して顕著 に表れ，短辺に対しては殆ど有意な差は生じなかった ${ }^{7)}$.これは, 板要素間での拘束効果は, 局部座屈耐力が高い板要素が局部座屈耐 力の低い板要素を拘束することに起因して生じるため, その逆であ る局部座屈耐力の低い板要素が局部座屈耐力の高い板要素を拘束す る効果は殆ど期待できないためであると考えられる。 そこで本論文 では, 隣り合う板要素間での拘束効果は, 局部座屈耐力の最も低い 板要素に発生するものと仮定したうえで, Eq.(14-1)〜(22)で各板要 素の負担軸力および曲げモーメントを計算し, 部材耐力を再評価し た。以下，本検討に用いた評価式を示寸．

Long side plate の弾性局部座屈耐力が低い場合

$$
\begin{aligned}
& M_{\mathrm{nlr}}=M_{1 \text { nnlr }}+M_{\mathrm{s} \_\mathrm{nl}} \\
& N_{\mathrm{nlr}}=N_{1 \_ \text {nlr }}+N_{\mathrm{s} \_ \text {nl }}
\end{aligned}
$$

Short side plate $の$ 弾性局部座屈耐力が低い場合

$$
\begin{aligned}
& M_{\mathrm{nlr}}=M_{1 \_n l}+M_{\mathrm{s} \_\mathrm{nlr}} \\
& N_{\mathrm{nlr}}=N_{1 \_\mathrm{nl}}+N_{\mathrm{s} \_\mathrm{nlr}}
\end{aligned}
$$

ただし $\quad M_{\mathrm{nlr}}$ : 計算耐力(拘束あり)

$M_{1 \_n l r}$ : 長辺板要素の負担モーメント耐力(拘束あり)

$M_{\perp \_n l}$ : 長辺板要素の負担モーメント耐力(拘束なし)

$M_{\mathrm{s} \_n l r}$ : 短辺板要素の負担モーメント(拘束あり)

$M_{\mathrm{s}_{\mathrm{n} n} \mathrm{n}}$ : 短辺板要素の負担モーメント(拘束なし)

$N_{\mathrm{nlr}}$ : 計算耐力(拘束あり)

$N_{1 \_n l r}$ : 長辺の負担軸力(拘束あり)

$N_{\mathrm{l} \_n l}$ : 長辺の負担軸力(拘束なし)

$N_{\mathrm{s} \text { nlr }}$ : 短辺の負担軸力 (拘束あり)

$N_{\mathrm{snl}}:$ 短辺の負担軸力 (拘束なし)

Eq.(23-1), (23-2)は長辺の板要素に拘束効果が表れることを想定し た耐力評価式である. 長辺の板側辺部に回転拘束が作用すると仮定

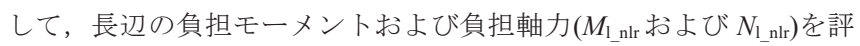
価した.また Eq.(24-1)，(24-2)は短辺に拘束効果が表れることを想定 した評価式である. 短辺の板側辺部に回転拘束が作用すると仮定し

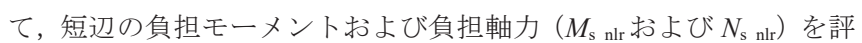
価した.

有限要素解析の結果から最大モーメント $M_{\mathrm{amx}}$ と $N_{\max }$ の比率 $\left(M_{\max } / N_{\max }\right)$ が等しい $M_{\mathrm{nl}} / N_{\mathrm{nl}}$ および $M_{\mathrm{nlr}}, N_{\mathrm{nlr}}$ を提案式から計算し, $M$ $N$ 曲面上で, 原点から最大耐力および計算耐力までの距離 $\left(l_{\max }, l_{\mathrm{n}}\right.$, および $\left.l_{\mathrm{nlr}}\right)$ の比率 $\left(l_{\max } / l_{\mathrm{nl}}, l_{\max } / l_{\mathrm{nlr}}\right)$ と $c / b$ との関係を調べることで, 断面形状の変化が部材の最大耐力の評価精度に及ぼす影響を分析し た. Fig.15 には, 板要素間での拘束効果を考慮した耐力評価の結果

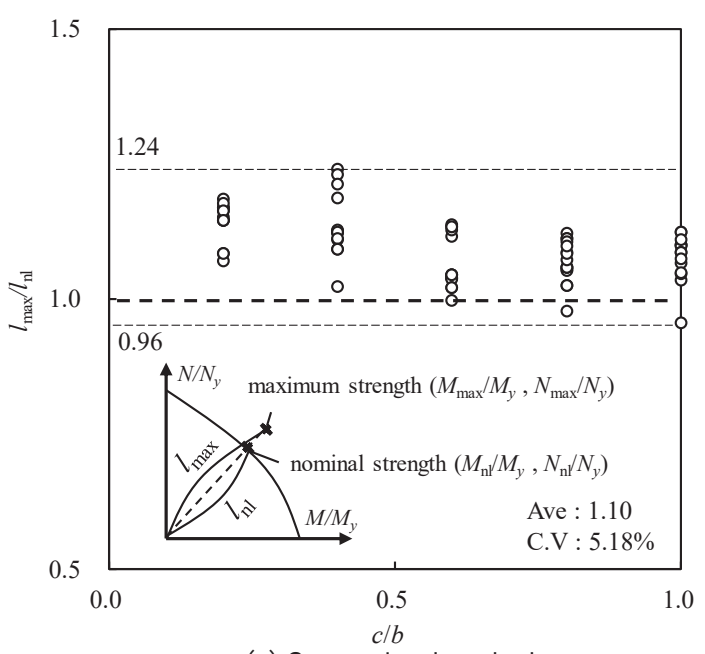

(a) Conventional method

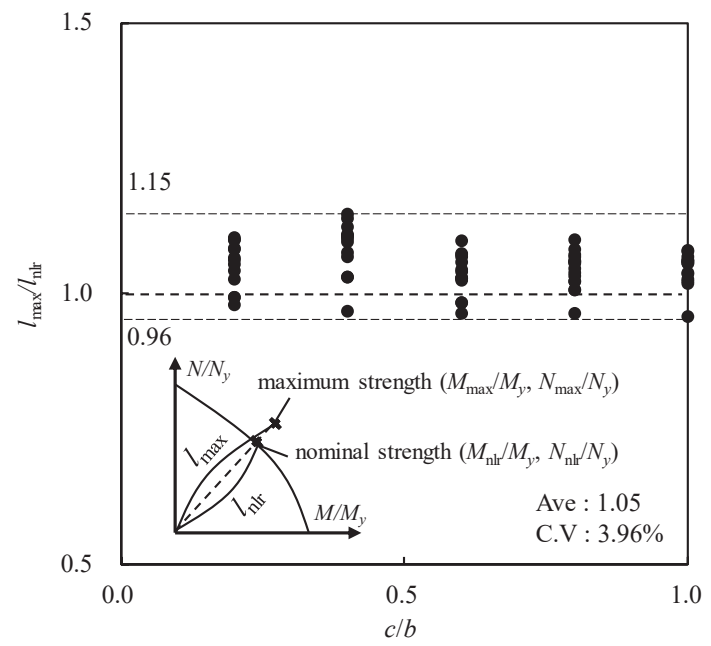

(b) Suggested method which is considered restraining

Fig.15 Ratio of the maximum strength with the nominal strength

と，拘束効果を無視した耐力評価結果との比較を示す. Fig15(a)が拘 束効果を無視した耐力評価值と解析結果との比率を表し, Fig15(b) が拘束効果を考慮した場合の結果を表す.

拘束効果による影響を無視した場合， $l_{\max } / l_{\mathrm{nl}}$ は 0.96 から 1.24 の間 に分布し，特に $c / b$ が小さい $c / b=0.2$ および 0.4 の解析において, $l_{\max } / l_{\mathrm{nl}}$ が大きくなる傾向を示した。この傾向は, 固有值解析で得られ た結果(Fig.10)と類似の傾向であり，隣り合う板要素間での拘束効果 によって計算耐力と最大耐力の差異が大きくなったものと推察する. 一方, 板要素間での拘束効果を考慮した解析結果では, $l_{\max } / l_{\mathrm{nlr}}$ が分 布する範囲は 0.96 から 1.15 に狭まり, $l_{\max } / l_{\mathrm{nlr}}$ の平均值も 1.10 から 1.05 に減少した. さらに変動係数についても, $3.96 \%$ まで減少してお り,$c / b$ が小さい断面仕様で $l_{\max } / l_{\mathrm{nlr}}$ が大きくなる傾向も確認されな かった．拘束効果による影響が最も大きく表れた $c / b=0.2$ の断面仕 様では, $y$ 軸まわりの弱軸曲げと圧縮力の複合力が作用した場合に, $l_{\mathrm{nlr}}$ が $l_{\mathrm{nl}}$ の比率は最大で 1.12 倍となり, 1 割以上の設計耐力の引き上 げが期待できる断面仕様も確認された。このように部材に板要素間 での拘束効果を考慮することで部材耐力を現行の基準に基づく設計 耐力よりも大きく評価することが可能になり，長方形断面部材の座 屈後耐力に対する評価精度を向上できる. 


\section{4. 結}

曲げと圧縮の複合力が作用する長方形断面を有する薄板軽量形鋼 の弾性局部座屈耐力および最大耐力に隣り合う板要素の板幅の違い が及ぼす影響を解析的に明らかにし，耐力評価手法を提案した。以 下，本検討を通じて得られた知見をまとめる。

・曲げ圧縮が作用する長方形断面部材の局部座屈耐力は, 断面を構 成する板要素を単純支持板とみなした場合の計算耐力よりも大きい 值となる.これは, 弾性局部座屈耐力および最大耐力の双方で確認 できる傾向であり, 長辺と短辺の辺幅の差が大きくなるほど影響が 顕著になる傾向を示寸. 長方形断面部材では, 断面を構成する板要 素によって弾性局部座屈耐力が異なるため, 局部座屈耐力の低い板 要素が, 局部座屈耐力の高い板要素によって板側辺部の回転変形を 拘束されたことで, 板要素の境界条件を単純支持とみなした場合の 計算耐力よりも高い局部座屈耐力が発揮された.

・軸圧縮と曲げの複合力が作用する長方形断面について, 板要素間 で回転拘束を考慮した弾性局部座屈耐力の評価式を提案した。提案 式は, 固有值解析に基づく計算耐力と良い対応を示し, 軸圧縮, 曲 げおよび曲げと圧縮の複合力が作用する長方形断面部材の弾性局部 座屈耐力を提案式で精度よく評価できる.

・隣り合う板要素間での拘束効果が部材の最大耐力に及ぼす影響を 評価する場合, 断面を構成する板要素のうち, 最も弾性局部座屈耐 力が低い板要素については端部拘束による影響を考慮して一般化幅 厚比を計算し, 他の板要素は単純支持板とみなして一般化幅厚比を 評価することで, 既存の設計式に基づく耐力評価の精度が向上する.

\section{参考文献}

1) Guide for Designing Cold-formed Steel Structures $2^{\text {nd }}$ Edition, Gihodo Shuppan Co.,Ltd. , 2014 (in Japanese) 薄板軽量形鋼造建築物設計の手引き 第 2 版, 技報堂出版, 2014

2) Von. Kármán, T. Sechler, E.E. and Donnell, L.H. : The Strength of Thin Plate in Compression, Transactions ASME, vol.54, APM 54-5, 1932

3) Winter, G. : Strength of Thin Steel Compression Flanges, Journal of Structural Engineering, ASCE, pp.527-576, 1946

4) North American Specification for the Design of Cold-Formed Steel Structural Members 2016 Edition, American Iron and Steel Institute, 2016

5) EN 1993-1-3 : Eurocode 3 - Design of Steel Structures, Part 1-3: General rules Supplementary rules for cold-formed members and sheeting, CEN - European committee for standardization, 2006

6) Kobashi, T. Nakayasu, N. Shimizu, N. Kanno, R. Ikarashi, K : Local Buckling Strength of Uniformly Compressed Octagonal Thin Walled Section Members, Journal of Structural and Construction Engineering (Transactions of AIJ). No.735, pp.713-722, 2017, 5 (in Japanese)

小橋知季, 中安誠明, 清水信孝, 菅野良一, 五十嵐規矩夫 : 軸圧縮が作用 する薄肉八角形断面部材の局部座屈而力, 日本建築学会構造系論文集, 第 735号, pp.713-722, 2017, 5

7) Kobashi, T. Ikarashi, K. Shimizu, N : Elastic Local Buckling Strength and Maximum Strength of Cold Formed Steel Members with Different Plate Width on Adjacent Plate Elements, Journal of Structural and Construction Engineering (Transactions of AIJ). No.749, pp.1051-1061, 2018, 7 (in Japanese)

小橋知季, 五十嵐規矩夫, 清水信孝 : 隣り合う板要素の幅が異なる薄板軽 量形鋼の弾性局部座屈耐力および最大耐力, 日本建築学会構造系論文集, 第749号, pp.1051-1061, 2018,7

8) Kobashi, T. Ikarashi, K. Shimizu, N : Evaluation of Local Buckling Strength on Octagonal Section Members, Proceedings of the Eighth International Conference on THIN-WALLED STRUCTURES, 2018, 7

9) Recommendations for Stability Design of Steel Structures, Architectural Institute of Japan, 2009 (in Japanese)

日本建築学会：鋼構造座屈設計指針, 2009座屈設計指針 10) Timoshenko, S. Gere, J. : Theory of elastic stability. McGraw-Hill, 1961

\section{付録A}

曲げが作用する長方形断面部材の弾性局部座屈について, $z$ 軸まわりの曲げが 作用する部材 (ただし, $1 \leqq b / c \leqq 2) の b / c$ との関係, ならびに $y$ 軸まわりの曲げが作 用する部材(ただし, $0<c / b \leqq 1) の c / b$ との関係をFig.1Aに示す. 部材は, いずれも 曲げが作用する際に一様な圧縮応力が作用寸る圧縮縁側の板要素が局部座屈す る断面仕様を有する. プロットが有限要素法による固有值解析から得た座屈モード を基に計算した た值であり, 破線がEq.(9-1) (9-3)ならびにEq.(10-1) (10-3)で計 算したハ值である. 図より, 解析結果と計算值は概ね良い対応を示し, 本論文での 提案式で, 曲げが作用する部材の $c / b$ または $b / c$ との関係を概ね評価できると言える。

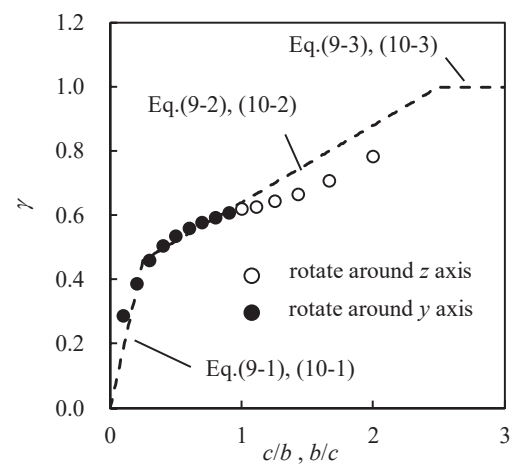

Fig. $1 \mathrm{~A} \gamma$ versus $c / b, b / c$

付録B

曲げ圧縮力が作用する場合の長方形断面部材の最大耐力を評価する場合, 荷 重条件には, 一定軸力下で曲げを作用させる方法と, 偏心曲げによって曲げと圧 縮を作用させる方法の2通りが想定される. そこで本報では, 口-100x40x0.8およびロ100x100x0.8の断面を有する部材を対象に, 上記の荷重条件の違いが部材耐力に 及ぼす影響を比較した. 結果をFig.2Aに示す. 黒プロットが一定軸力下で曲げが 作用寸る場合の解析結果であり, 白プロットが偏心圧縮による解析結果である. 両 解析結果はいずれも同一直線状に分布することが確認でき, 載荷方法の違いが最 大耐力に及ぼす影響は殆どなかった. 幅厚比が十分に大きい薄板軽量形鋼の場 合, 部材の最大耐力は断面内の発生応力が降伏強度に達した時点で決まる. した がって最大耐力時において部材の大部分は塑性化には至っておらず, 載荷方法 の違いが最大耐力時の応力分布にほとんじ影響を及ぼさなかったものと推察する. 以上の検討結果から, 本論文では現実の境界条件に近いと考えられる偏心圧縮に より曲げと圧縮の複合力を作用させる荷重条件を採用した.

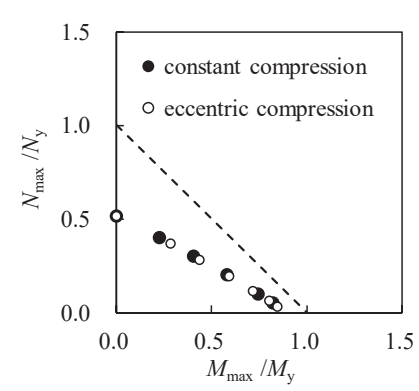

(a) $\square-100 \times 40 \times 0.8$

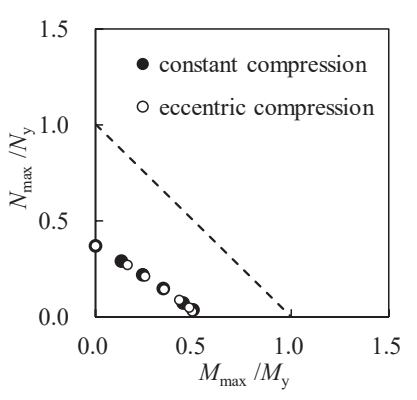

(b) $\square-100 \times 100 \times 0.8$
Fig.2A Effect of the load difference

(eccentric compression or combined load with constant compression and bending) 


\title{
ELASTIC LOCAL BUCKLING STRENGTH AND MAXIMUM STRENGTH OF RECTANGULAR SECTION MEMBERS WHICH WERE LOADED COMPRESSION AND BENDING
}

\author{
Tomoki KOBASHI ${ }^{* 1}$, Kikuo IKARASHI ${ }^{* 2}$ and Nobutaka SHIMIZU ${ }^{* 3}$ \\ ${ }^{* 1}$ Researcher, Steel Structures Research Lab., Nippon Steel \& Sumitomo Metal Corporation, M.Eng. \\ Grad. Student, Dept. of Architecture and Building Engineering, Tokyo Institute of Technology \\ ${ }^{* 2}$ Prof., Dept. of Architecture and Building Engineering, Tokyo Institute of Technology, Dr.Eng. \\ ${ }^{*} 3$ Senior Researcher, Steel Structures Research Lab., Nippon Steel \& Sumitomo Metal Corporation, Dr.Eng.
}

Cold-formed steel members were composed of thin plate elements thus the members were easily occurred the local buckling under compression. The local buckling strength significantly affects the maximum strength of the members, therefore providing an accurate evaluation method for the local buckling strength is one of the key issues in their design. The conventional design method was assumed that the plate elements behave as a simply supported plate element. However, the longitudinal edges of plate elements were restrained their rotation by adjacent plate elements, and this restraining might lead an increase of local buckling strength of cold formed members both in the case of elastic and inelastic.

In this paper, we investigated the restraining effect on rectangular section under combined compression and bending condition. First, we conducted the eigenvalue analysis by finite strip method. Through the comparison between numerical analysis results and theoretical results which assumed simply supported condition, we found that the restraining effect was appeared not only under axially compressed loading condition but also under combined loading condition.

Then, we considered evaluating the elastic local buckling strength under combined compression and bending condition by the equations which we had developed for axially compressed members. Through the comparison between eigenvalue analysis results and calculated results, we found that the elastic local buckling strength of rectangular sections under bending and compression could be evaluate the developed equations accurately with a tiny modification.

Finally, we conducted a finite element analysis to investigate the restraining effect on inelastic strength (i.e. maximum strength) of rectangular section members. The maximum strength of rectangular sections was mostly higher than the nominal strength which assumed the boundary condition as a simply supported condition. Furthermore, we re-evaluated their maximum strength with a consideration of restraining. The re-evaluated results were agreed well with the numerical analyses, thus we found that the maximum strength of rectangular sections was evaluated accurately to consider the restraining effect between adjacent plate elements compared with the conventional method which regard the plate elements as a simply supported plate. 